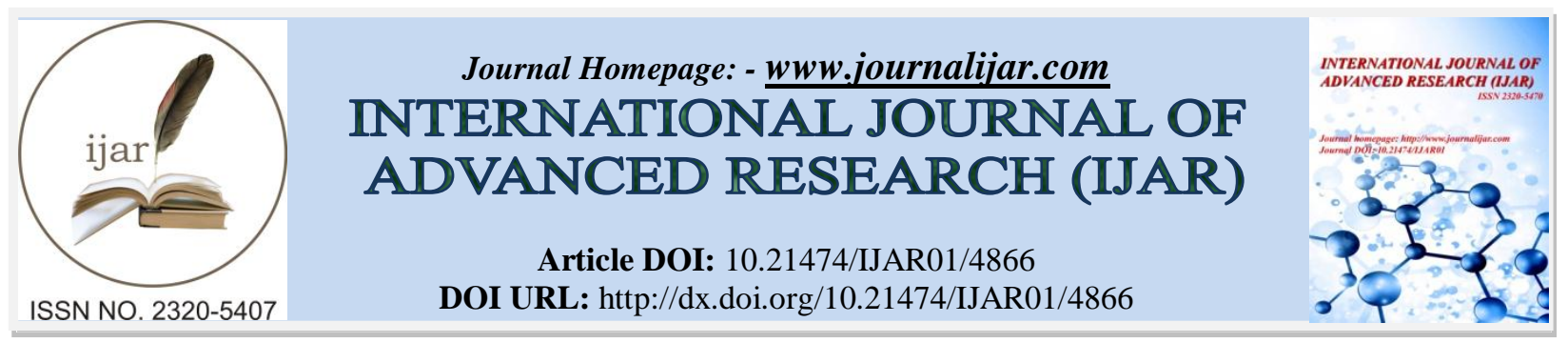

RESEARCH ARTICLE

\title{
GC-MS ANALYSIS AND ANTIMICROBIAL ACTIVITY OF SAUDI FOENICULUM VULGARE MILL.(APIACEAE) FIXED OIL.
}

\author{
Abdel Karim. M. ${ }^{{ }^{*}}$, Ayda A. ${ }^{2}$ and Khalid M.S. ${ }^{3}$. \\ 1. Sudan University of Science and Technology, Faculty of Science, Dept. of Chemistry. \\ 2. Najran University,Faculty of Science and Arts, Dept. of Chemistry. \\ 3. International University of Africa, Faculty of Pharmacy.
}

\section{Manuscript Info}

Manuscript History

Received: 16 May 2017

Final Accepted: 18 June 2017

Published: July 2017

Key words:-

Foeniculum vulgare, Fixed oil, GC-MS, Antimicrobial activity

\section{Abstract}

Foeniculum vulgare seed oil was studied by GC-MS. The oil was also assessed for antimicrobial activity. Thirty two components were detected by GC-MS analysis. Main constituents are: 9-octadecenoic acid methyl ester(48.54\%), 9,12-octadecadienoic acid methyl ester(28.50\%), $\gamma$-terpinene(4.98\%), and $\beta$-pinene(3.51\%).The antibacterial activity of the oil was evaluated via the diffusion assay against five standard human pathogens(Gram positive: Staphylococcus aureus and Bacillus subtilis; Gram negative : Escherichia coli and Pseudomonasa aeruginosa and the fungus Candida albicans). Foeniculum vulgae oil showed excellent activity against Staphylococcus aureus in the concentration range : $100-25 \mathrm{mg} / \mathrm{ml}$. It also exhibited significant activity against the yeast Candida albicans at $100 \mathrm{mg} / \mathrm{ml}$..It seems that the oil is a lead for further optimization.

Copy Right, IJAR, 2017,. All rights reserved.

\section{Introduction:-}

Fennel (Foeniculum vulgare Mill.) is a perennial herb, with feathering leaves, in the family Apiaceae. The plant is cultivated worldwide for its economic value as a flavouring agent in baked foods(Diaaz, 2005 , 2006). The plant contains : $\operatorname{protein}(9.5 \%)$; fats $(10 \%)$; minerals $(\mathrm{Ca}, \mathrm{K}, \mathrm{Na}, \mathrm{Fe}$ and $\mathrm{P}), 13.4 \%)$; fibre(18.5\%) beside niacin, riboflavin and thiamine(Manzoor,2016).

Fennel is added to purgatives to allay their side effects. Seeds are claimed to improve eyesight if taken raw while seed extract has been tested against glaucoma in model animals. Seeds are also diuretic and hypotensive.(Agrawal,2008).

The potential pharmacological effect of fennel seems to be associated with its volatile oil which contains, among others, anethole, fenchone, estragol, p- anisaldehyde and $\alpha$-phellandrene(Diiaz,2006). Anisole is claimed to possess estrogenic properties(Tognolini, 2007).

Some quercetin and kaempferol conjugates have been isolated from from fennel(Faudale,2008; park,1996 , Parejo,2004). Such phenolics are responsible for the free radical scavengaging capacity of fennel. Sterols, sugars , acetylated kaempferol and some benzoisofuranone derivatives were identified in fruits(Marino,2007, Soliman,2002). Beside its health promoting properties, a main constituent of fennel- leugenol- has become a cause of concern since the structurally related ,methylleugenol was reported as a potential carcinogenic agent(Zeller,2006). 


\section{Materials and Methods:-}

\section{Plant material:-}

The seeds of Foeniculum vulgare were collected from around Najran, Saudi Arabia.The plant was authenticated by direct comparison with a herbarium sample.

\section{Test organisms:-}

Foeniculum vulgae oil was screened for antimicrobial activity using the standard bacterial strains: Bacillus subtilis $(\mathrm{Gram}+\mathrm{ve})$, Staphylococcus aureus $(\mathrm{Gram}+\mathrm{ve})$, Pseudomonas aeroginosa $(\mathrm{Gram}-\mathrm{ve})$, Escherichia coli $(\mathrm{Gram}-$ ve) and the fungal species Candida albicans.

\section{Methods:-}

\section{Extraction of Foeniculum vulgare seed oil:-}

Powdered seeds of Foeniculum vulgare (300g) were macerated with n-hexane at ambient temperature for 48h..The solvent was removed in vacuo to afford the oil. Esterification of the oil, for GC-MS analysis, was accomplished via a methanolic solution of sodium hydroxide and a methanolic sulphuric acid.

\section{GC-MS Analysis:-}

A Shimadzo Ultra instrument was used for GC-MS analysis of Foeniculum vulgare fixed oil. RTX-5MS column (30m,length ; $0.25 \mathrm{~mm}$ diameter ; $0.25 \mu \mathrm{m}$, thickness) was used. Analytical grade helium (purity; $99.99 \%$ ) was the carrier gas. Oven temperature program is displayed below, while other chromatographic conditions are depicted in Tables 1 .

Rate: - ; Tempt.,60.0 ${ }^{\circ} \mathrm{C}$; Hold time $\left(\mathrm{min}^{-1}\right), 0.00$

Rate, 10.0 ; Tempt.,300.0 ; Hold time $\left(\mathrm{min}^{-1}\right), 0.00$

Table 1:- Chromatographic conditions

\begin{tabular}{l|l} 
Column oven temperature & $1300.0{ }^{\circ} \mathrm{C}$ \\
Injection temperature & $280.0{ }^{\circ} \mathrm{C}$ \\
Injection mode & Split \\
Flow control mode & Linear velocity \\
Pressure & $93.1 \mathrm{KPa}$ \\
Total flow & $50.0 \mathrm{ml} / \mathrm{min}$ \\
Column flow & $1.50 \mathrm{ml} / \mathrm{sec}$ \\
Linear velocity. & $44.7 \mathrm{~cm} / \mathrm{sec}$ \\
Purge flow & $3.0 \mathrm{ml} / \mathrm{min}$. \\
Spilt ratio & -1.0 \\
\hline
\end{tabular}

\section{Antimicrobial assay:-}

Preparation of bacterial suspensions:-

Diffusion method was the method used for screening the oil. Mueller Hinton and Sabouraud dextrose agars were the media used as the growth media for the bacteria and the fungi respectively. The media were prepared according to the manufacturer's instructions.

Aliquots $(1 \mathrm{ml})$ of 24 hours broth culture of the test microorganisms were aseptically distributed onto nutrient agar slopes and incubated at $37^{\circ} \mathrm{C}$ for 24 hours. Bacterial growth was harvested and washed off with sterile normal saline , then it was suspended in (100 ml) of normal saline to afford about 108-109 colony forming units per ml. Average number of viable organism per $\mathrm{ml}$ of the stock suspension was determined by means of the surface viable counting technique. Serial dilutions of the stock suspension were made in sterile normal saline. $(0.02 \mathrm{ml})$ of the appropriate dilutions were transferred onto the surface of dried nutrient agar plates. The plates were allowed to stand for two hours at room temperature and then incubated at $37^{\circ} \mathrm{C}$ for 24 hours.

Fungal cultures were maintained on Sabouraud dextrose agar incubated at $25^{\circ} \mathrm{C}$ for four days. The fungal growth was harvested and washed with sterile normal saline, and the suspension was stored in the refrigerator until used. 


\section{Testing for Antibacterial Activity:-}

$(2 \mathrm{ml})$ of the standardized bacterial stock suspension were mixed with $(200 \mathrm{ml})$ of sterile molten nutrient agar which was maintained at $45^{\circ} \mathrm{C}$. $(20 \mathrm{ml})$ Aliquots of the incubated nutrient agar were distributed into sterile Petri dishes. The agar was left to settle. Each plate was divided into two halves. In each half two cups (10mm in diameter) were cut using sterile cork borer (No 4). Each half was designed for a test solution.

Agar discs were removed, alternate cups were filled with $(0.1 \mathrm{ml})$ samples of each test solution and allowed to diffuse at room temperature for two hours. The plates were then incubated at $37^{\circ} \mathrm{C}$ for 24 hours. After incubation, the diameters of the resultant growth inhibition zones were measured in duplicates and averaged.

\section{Results and Discussion:-}

GC-MS analysis of Foeniculum vulgae fixed oil:-

GC-MS analysis of Foeniculum vulgae fixed oil was carried out. The MS library (NIST) was checked for identification of the constituents (a 90-95\% match was observed). Furthermore, the observed fragmentation pattern was interpreted.

The GC-MS analysis of the studied oil revealed the presence of 32 components(Table 2). The typical total ion chromatograms (TIC) is depicted in Fig.1.

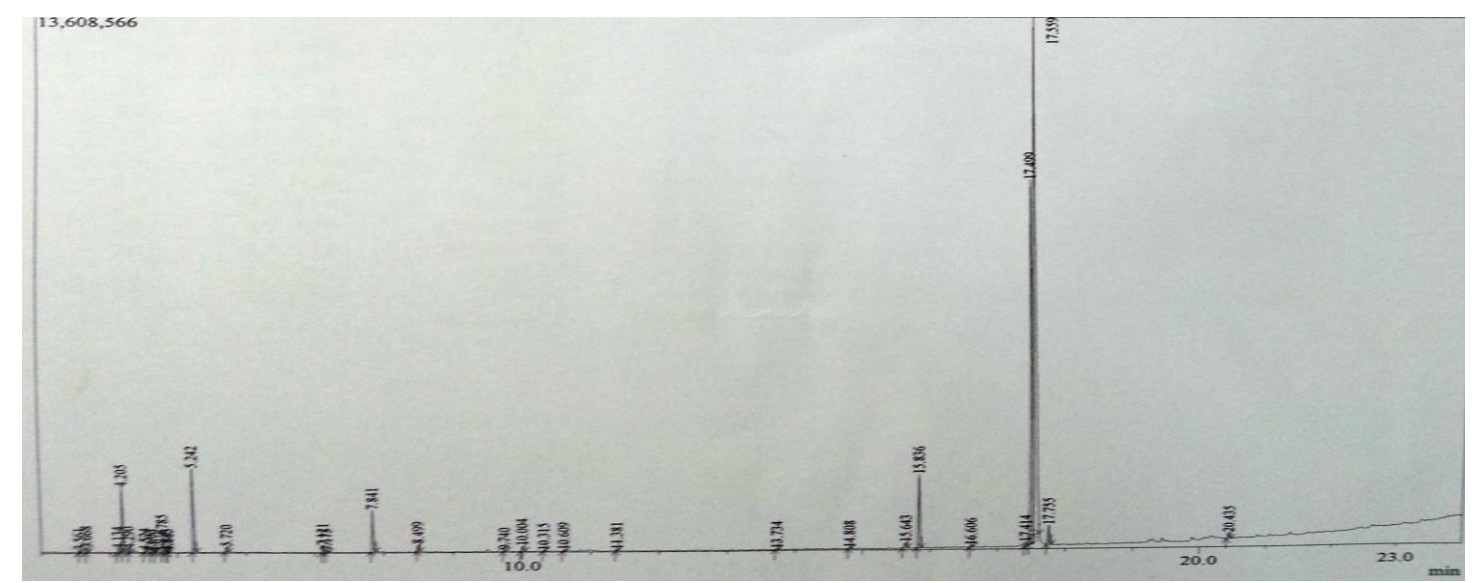

Fig.1:- Total ion chromatograms 
Table 2: Contituents of Foeniculum vulgae oil

\begin{tabular}{|c|c|c|c|c|}
\hline \multirow{2}{*}{\multicolumn{5}{|c|}{ Area $\%$ Name }} \\
\hline & & & & \\
\hline$\frac{1}{2}$ & 3.561 & 78697 & 0.13 & $\begin{array}{l}\text { Bicyclo[3.1.0]hex-2-ene, 2-methyl-5-(1-mei } \\
\text { alpha-Pinene }\end{array}$ \\
\hline$\frac{2}{3}$ & 3.668 & 149117 & 0.25 & $\begin{array}{l}\text {.alpha.-Pinene } \\
\text { Bicyclo[3.1.0]hexane, 4-methylene-1-(1-me }\end{array}$ \\
\hline $\begin{array}{l}3 \\
4\end{array}$ & 4.134 & 163802 & 0.27 & Bicyclo[3.1.0]hexane, 4-methylene-1-(1-me \\
\hline $\begin{array}{l}4 \\
5\end{array}$ & 4.205 & 2134541 & 3.51 & .beta.-Pinene \\
\hline$\frac{5}{6}$ & 4.290 & 123090 & 0.20 & .beta.-Myrcene \\
\hline$\frac{6}{7}$ & 4.524 & 62880 & 0.10 & .alpha.-Phellandrene \\
\hline $\begin{array}{l}7 \\
8\end{array}$ & 4.603 & 16082 & 0.03 & 3-Carene \\
\hline $\begin{array}{l}8 \\
9\end{array}$ & 4.679 & 18436 & 0.03 & $(+)$-4-Carene \\
\hline 10 & $\begin{array}{l}4.785 \\
4.843\end{array}$ & 48379 & 0.08 & $\begin{array}{l}\text { o-Cymene } \\
\text { D-Limonene }\end{array}$ \\
\hline 11 & 4.865 & 42651 & 0.07 & .beta.-Phellandrene \\
\hline 12 & 5.242 & 3027403 & 4.98 & .gamma.-Terpinene \\
\hline 13 & 5.720 & 172319 & 0.28 & Undecane \\
\hline 14 & 7.121 & 253023 & $\mathbf{0 . 4 2}$ & Dodecane \\
\hline 15 & 7.175 & 86329 & 0.14 & 1-Cyclohexene-1-carboxaldehyde, 4-(1-me \\
\hline 16 & 7.841 & 1719357 & 2.83 & Benzaldehyde, 4-(1-methylethyl)- \\
\hline 17 & 8.499 & 281517 & 0.46 & Tridecane \\
\hline 18 & 9.740 & 54609 & 0.09 & Naphthalene, $1,2,3,4,4 a, 5,6,8$ a-octahydro- \\
\hline 19 & 10.004 & 210440 & 0.35 & Benzenepropanol, 4-methoxy- \\
\hline 20 & 10.315 & 30972 & 0.05 & Caryophyllene \\
\hline 21 & 10.609 & 70725 & 0.12 & (E)-.beta.-Famesene \\
\hline 22 & 11.381 & 49224 & 0.08 & Butylated Hydroxytoluene \\
\hline 23 & 13.734 & 37259 & 0.06 & Methyl tetradecanoate \\
\hline 24 & 14.808 & 33780 & 0.06 & Pentadecanoic acid, methyl ester \\
\hline 25 & 15.643 & 336214 & 0.55 & 9-Hexadecenoic acid, methyl ester, (Z)- \\
\hline 26 & 15.836 & 2902997 & 4.78 & Hexadecanoic acid, methyl ester \\
\hline 27 & 16.606 & 76436 & 0.13 & Methyl 8-heptadecenoate \\
\hline 29 & 17.499 & 17325881 & 28.50 & 9,12-Octadecadienoic acid $(\mathrm{Z}, \mathrm{Z})-$, methyl \\
\hline 30 & 17.559 & 29508900 & 48.54 & 9-Octadecenoic acid (Z)-, methyl ester \\
\hline 31 & 17.755 & $\mathbf{8 2 5 7 2 9}$ & 1.36 & Methyl stearate \\
\hline 32 & 20.435 & 279634 & 0.46 & Phenol, 2,2'-methylenebis $[6-(1,1$-dimethyl \\
\hline
\end{tabular}

Main constituents of the oil are discussed below:

9-Z-Octadecenoic acid methyl ester( $48.54 \% \%)$

Fig. 2 shows the EI mass spectrum of 9-octadecenoic acid methyl ester.The peak at $\mathrm{m} / \mathrm{z} 296$, which appeared at R.T. 17.559 in total ion chromatogram, corresponds to $\mathrm{M}^{+}\left[\mathrm{C}_{19} \mathrm{H}_{36} \mathrm{O}_{2}\right]^{+}$, while the peak at $\mathrm{m} / \mathrm{z} 266$ accounts for loss of a methoxyl function

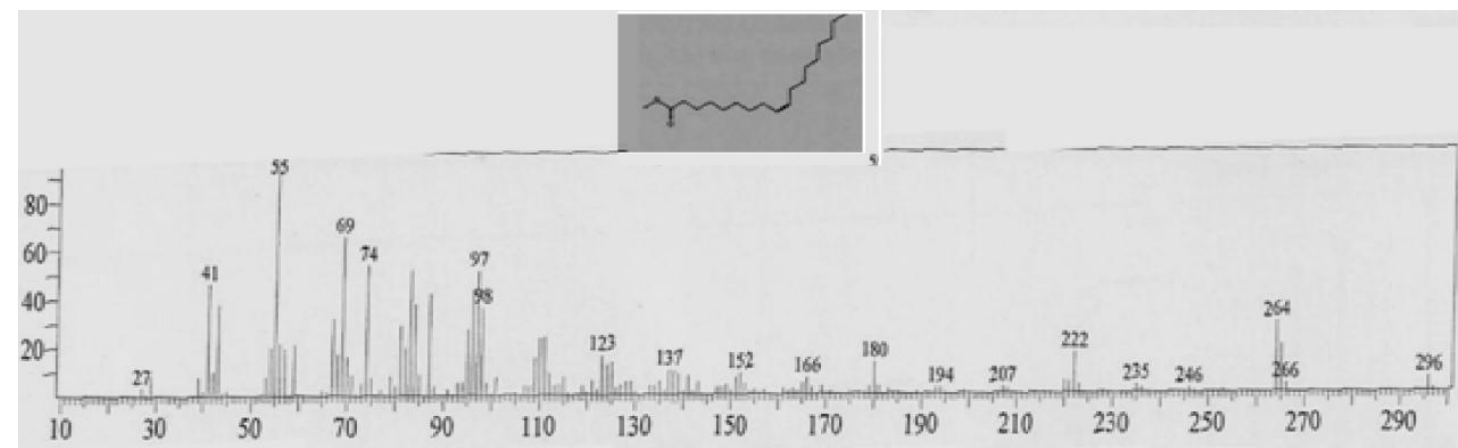

Fig. 2:- Mass spectrum of 9-octadecenoic acid methyl ester.

\section{9,12-Z,Z-Octadecadienoic acid methyl ester (28.50\%)}

The mass spectrum of 9,12-octadecadienoic acid methyl ester is displayed in Fig.3.The peak at m/z294( R.T. 17.499-in total ion chromatogram)) corresponds $\mathrm{M}^{+}\left[\mathrm{C}_{19} \mathrm{H}_{34} \mathrm{O}_{2}\right]^{+}$. The signal at $\mathrm{m} / \mathrm{z} 263$ corresponds to loss of a methoxyl function. 


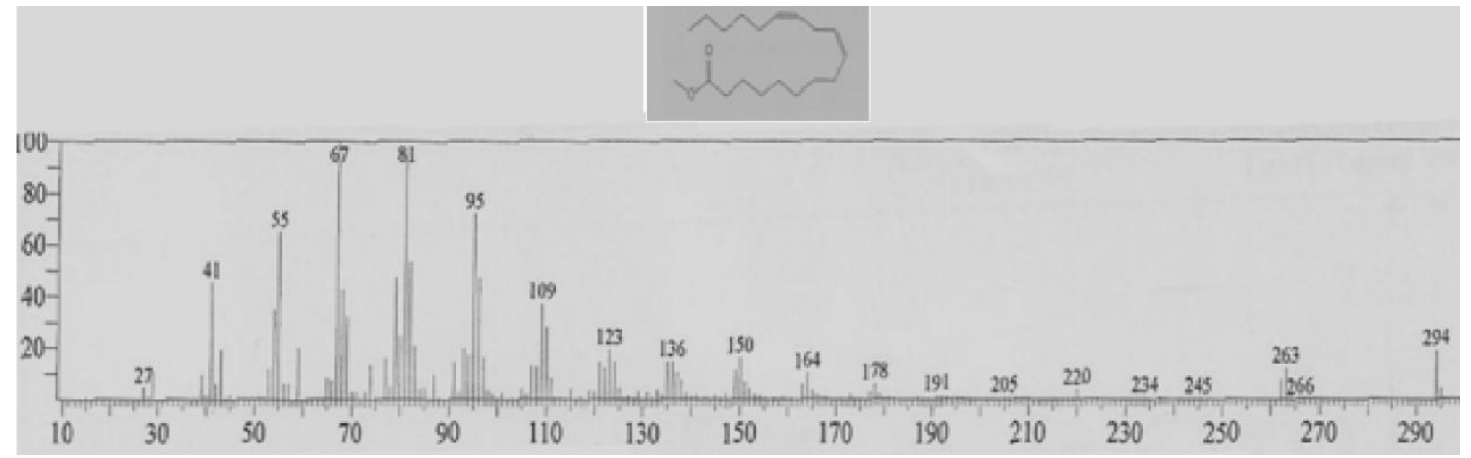

\section{$\gamma$ - Terpinene(4.98\%)}

Fig. 3:- Mass spectrum of 9,12-octadecadienoic acid methyl ester

Fig. 4 shows the mass spectrum of $\gamma$-terpinene .The peak at $\mathrm{m} / \mathrm{z} 136$, which appeared at R.T. 5.242 in total ion chromatogram, corresponds $\mathrm{M}^{+}\left[\mathrm{C}_{10} \mathrm{H}_{16}\right]^{+}$.

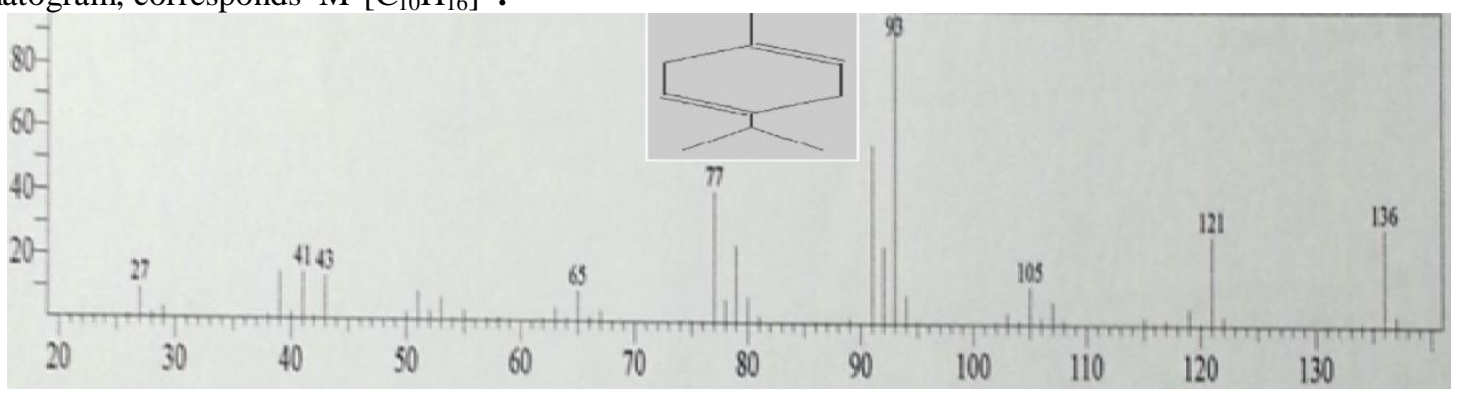

Fig. 4:- Mass spectrum of $\boldsymbol{\gamma}$ - terpinene

\section{B-Pinene( 3.51\%)}

The masss spectrum of $\beta$-Pinene is shown in Fig.5. The molecular ion $\mathrm{M}^{+}\left(\mathrm{C}_{10} \mathrm{H}_{16}\right)$ appeared at $\mathrm{m} / \mathrm{z} 136$ with $\mathrm{RT}, 4.205$ in total ion chromatogram.

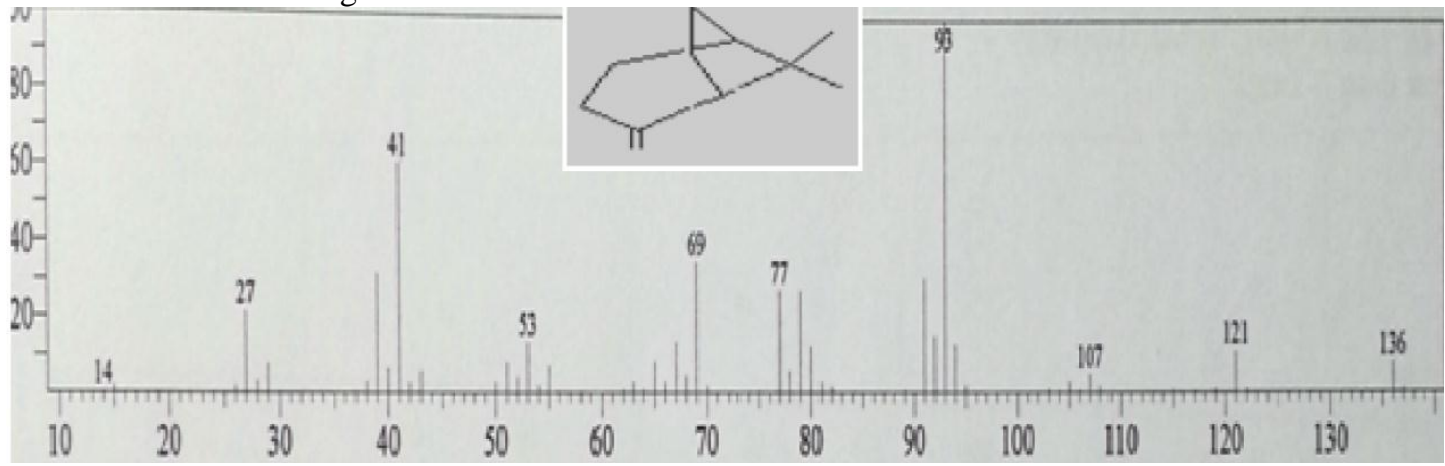

Fig. 4:- Mass spectrum of $\beta$-pinene

\section{Antibacterial activity}

Foeniculum vulgae oil was screened for antimicrobial activity against five standard bacterial strains . The diameters of the growth of inhibition zones are shown in Table (3). Conventional terms were used for interpretation of the results : ( $<9 \mathrm{~mm}$ : inative;9-12mm:partially active;13-18mm: active; $>18 \mathrm{~mm}$ :very active) .Tables (4) and (5) represent the antimicrobial activity of standard drugs.

Table 3:- Antibacterial activity of Foeniculum vulgae oil

\begin{tabular}{|c|c|c|c|c|c|c|}
\hline Type & Conc. $(\mathrm{mg} / \mathrm{ml})$ & $\mathbf{S a}$ & Bs & Ec & Ps & $\mathrm{Ca}$ \\
\hline \multirow[t]{5}{*}{ Oil } & 100 & 20 & 14 & 15 & 15 & 17 \\
\hline & 50 & 18 & - & 14 & 14 & 15 \\
\hline & 25 & 17 & - & 13 & 13 & 10 \\
\hline & 12.5 & 15 & - & 12 & 12 & 9 \\
\hline & 6.25 & 11 & - & 10 & 7 & - \\
\hline
\end{tabular}


Table 4:- Antibacterial activity of standard chemotherapeutic agents

\begin{tabular}{|c|c|c|c|c|c|}
\hline Drug & Conc. $(\mathrm{mg} / \mathrm{ml})$ & Bs & Sa & Ec & Ps \\
\hline Ampicilin & 40 & 15 & 30 & - & - \\
& 20 & 14 & 25 & - & - \\
& 10 & 11 & 15 & - & - \\
\hline Gentamycin & 40 & 25 & 19 & 22 & 21 \\
& 20 & 22 & 18 & 18 & 15 \\
& 10 & 17 & 14 & 15 & 12 \\
\hline
\end{tabular}

Table 5:- Antifungal activity of standard chemotherapeutic agent

\begin{tabular}{|l|l|l|l|}
\hline Drug & Conc. $(\mathrm{mg} / \mathrm{ml})$ & An & Ca \\
\hline Clotrimazole & 30 & 22 & 38 \\
& 15 & 17 & 31 \\
& 7.5 & 16 & 29 \\
\hline
\end{tabular}

Sa.: Staphylococcus aureus

Ec.: Escherichia coli

Pa.: Pseudomonas aeruginosa

An.: Aspergillus niger

Ca.: Candida albicans

$\square$ Bs.: Bacillus subtilis

Foeniculum vulgae oil showed excellent activity against Staphylococcus aureus in the concentration range : 100$25 \mathrm{mg} / \mathrm{ml}$. It also exhibited significant activity against the yeast Candida albicans at 100mg/ml.

\section{References:-}

1. Agarwal,R., Gupta,S.K., Agarwal,S.S., Srivastava,S., R. Saxena, R., Indian J. Physiol. Pharmacol., (2008),52, 77.

2. Diaaz-Moroto,M.C.,Hidalgo,I.J.,Saanchez-Palomo,E.,Pearez-Coello,M.S., J. Agric. Food Chem.,2005,53,6814.

3. Diaaz-Moroto,M.C.,Pearez-Coello,M.S.,Esteban,J.,Sanz,J., J. Agric. $\quad$ Food Chem.,2006,54,6814.

4. Faudale,M., Viladomat,F., Bastida,J., Poli,F., Codina,C., J. Agric. Food Chem.,2008, 56, 1912.

5. Manzoor,A.,Bilal,A.D.,Shahnawaz,N.,Bilal,A.B.,Mushtaq,A., Arabian Journal of Chemistry,2016,9(2),S1574.

6. Marino,S.D., Gala,F., Borbone,N., Zollo,F., Vitalini,S., F. Visioli,F., Iorizzi ,M., Phytochemistry,2007, 68 , 1805.

7. Park, H.J., J. Nat. Prod.,1996, 59, 1128.

8. Parejo,I.,Viladomat,F., Bastida,J., Schmeda-Hirschmann,G., Burillo,J., Codina,C., J. Agric. Food Chem.,2004, 52,1890.

9. Soliman,F.M., Shehata,A.F., Khaleel,A.E., S.M. Ezzat,S.M., Molecules,2002, 7 , 245.

10. Tognolini,M., Ballabeni,V., Bertoni,S., Bruni,R., Impicciatore,M., E. Barocelli , E., Pharmacol. Res., 2007),56, 254.

11. Zeller,A., M. Rychlik, M., J. Agric. Food Chem.,2006, 54 ,3686. 